\title{
Öğretim Elemanlarının Örgütsel Bağlılığa İlişkin Görüşleri: Bir Durum Çalışması ${ }^{1}$
}

\author{
DOI: 10.26466/opus.543495 \\ * \\ Soner Doğan* - Ayşad Gonca Güner** \\ * Doç. Dr, Cumhuriyet Üniversitesi, Eğitim Fakültesi, Sivas / Türkiye

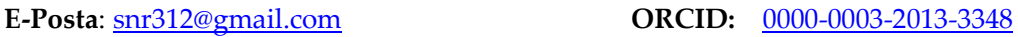 \\ ** Giresun Üniversitesi Şebinkarahisar Meslek Yüksekokulu, / Giresun/ Türkiye \\ E-Posta: goncainalkac@hotmail.com \\ ORCID: $\quad$ 0000-0001-7228-2244
}

Öz

Bu araştırmanın amacı, öğretim elemanlarının kurumlarına ilişkin örgütsel bă̆gllık düzeyini öğretim elemanlarının görüşlerine göre değerlendirmektir. Araştırma nitel durum çalışması desenine göre yapılandırılmış olup, veriler araştırmacılar tarafından geliştirilen yarı yapılandırılmış görüşme formu aracılığıyla toplanmıştır. Araştırmanın çalışma grubunu Giresun Üniversitesi bünyesinde yer alan 11 meslek yüksekokulunda görev yapan 22 öğretim elemanından oluşturmaktadır. Katılımcılarla yüz yüze yapılan görüşmeler sonucu elde edilen veriler, içerik ve betimsel analiz yöntemleri ile analiz edilerek kategoriler ve temalar elde edilmiştir. Araştırma bulgularına göre öğretim elemanlarının kurumlarına bağlllık göstermelerini sağlayan faktörler; kurumda var olan iletişimin sağglklı olması, çalışma ortamının esnekliği, kuruma karşı duyulan güven, kurum kültürüne uyumun sağlanması olarak özetlenebilir. Öğretim elemanlarının kurumlarına bağlllık göstermelerini engelleyen faktörler ise; kadro yetersizlĭgi, fiziki ve sosyal imkân yetersizlĭ̆i, ulaşım zorluğu, yaşanan çatışmalar ve gruplaşmalar olarak ifade edilebilir. Bulgular genel olarak değerlendirildiğinde öğretim elemanlarının kurumlarına ilişkin bağgllık düzeyleri duygusal, normatif ve devam bağlllı̆̆l şeklinde stralanabilir. Araştırma bulgularına göre kurumda örgütsel bağhllı̆̆ı güçlendirmeye yönelik öneriler geliştirilmiştir.

Anahtar Kelimeler: Öğretim elemanı, örgütsel bağlllık, meslek yüksekokulu

\footnotetext{
${ }^{1}$ Bu çalışma, Doç. Dr. Soner DOĞAN danışmanlığında Ayşad Gonca GÜNER tarafından hazırlanan yüksek lisans tezinden faydalanılarak derlenmiştir.
} 


\title{
Opinions of Instructors On Organizational Commitment: A Case Study
}

\begin{abstract}
The study aims to assess the instructors' level of organizational commitment to their institutions based on their views. The study was structured according to the qualitative case study pattern and the data were collected using a semi-structured interview form developed by the researchers. The study group included 22 instructors who worked in 11 vocational schools in Giresun University. Categories and themes were obtained analyzing the data received as a result of the face-to-face interviews with the participants using content and descriptive analysis methods. According to the findings of the study, the factors that enable instructors to provide commitment to their institutions were as follows: healthy communication in the institution, flexibility of the working environment, trust toward the institution and adaptation to the corporate culture. Lack of staff, inadequacy of physical and social facilities, difficulties in transportation, conflicts and grouping were the factors that prevented instructors to provide commitment to their institutions. instructors' level of commitment to their institutions could be listed as emotional, normative and continuity commitment when evaluated the results. According to the findings of the research, suggestions for strengthening the organizational commitment in the institution have been developed.
\end{abstract}

Keywords: Instructor, organizational commitment, vocational school 


\section{Giriş}

Bireyler, çalışan olarak örgütlerde kendilerine verilen iş tanımları doğrultusunda görev yapmaktadır. Örgütler, çalışanlardan iş tanımları doğrultusunda davranmaların beklemekle birlikte informal ilişkiler bağlamında örgüt için fedakârlık yapılmasını da arzu etmektedir. Bu bağlamda örgütün gelişimi ve devamlılığı açısından çalışanların örgüte bakış açıları ve örgütü benimseme davranışları önem kazanmaktadır. Her örgüt çalışanları tarafından kabul görmek ve onların hizmetlerini en iyi şekilde yerine getirmesini bekler. Bu beklentilerin karşılanmasında çalışanların örgüte olan güveni, inanc, sevgisi ve tüm bunların bileşkesi olan bağlılığı günümüz yönetim anlayışı içerisinde ön plana çıkmaktadır. Cooper-Hakim ve Viswesvaran (2005) geçtiğimiz otuz yıl boyunca, örgütsel bağlılığın doğasını, öncüllerini ve sonuçlarını anlamak için etkileyici miktarda araştırma yapılmıştır. Bu araştırmalara göre yüksek düzeyde çalışan bağlılığı örgütün gelişimine önemli katkılar yapmaktadir.

Örgütsel bağl1lığa ilişkin yapılan araştırmalar bağlılı̆̆ı genellikle bir tutum ya da davranış olarak ele almış ve psikolojik bir olgu olarak sunmuştur (Fisher ve Boyle ve Fulop, 2010). Bu bağlamda çalışanın, fayda sağlayacağ1 durumlardan çok örgütü düşünerek, örgüte duygusal bağlllık geliştirmesi ve (Sökmen, 2000) sahip olduğu birikimi, bağl1lı̆̆1 örgütün sosyal yapısına iletme çabası örgütsel bağlılığın göstergesi olarak kabul edilmektedir (Gözen, 2007). Örgütsel bağlılık ile çalışanların örgütün bir parçası haline getirilmesi, örgütün beklentileri ile çalışanın beklentilerinin belli bir noktada buluşturulması amaçlanmaktadır (Yıldız, Akbolat ve Işık, 2013). Örgütsel bağlılık alanında yapılan çalışmalardan elde edilen bulgulara göre işverenler, çalışanların düşünce üretmelerini, karar verme süreçlerinde yer almalarını, insiyatif alarak örgüte fayda sağlamalarını beklemektedir (Simon, 1991). Bu nedenle örgütte başarıyı artıracak stratejilerin uygulanması için örgütsel bağlılık önem arz etmektedir (Joiner ve Bakalis, 2006).

Bireyler ve örgütler arasında örgütsel bağllı̆̆a ihtiyaç vardır. Örgütsel bağlılık, yönetim ve davranış bilimleri literatüründe bireyler ve örgütler arasındaki ilişkide anahtar bir unsur olarak geniş bir şekilde çerçevede tanımlanmaktadır (Adekola, 2012). Üretim faktörlerinin 
olmazsa olmazı olan insan faktörüne yeni yönetim anlayışında daha çok ihtiyaç duyulmakta, iş gören örgüt ilişkisi daha fazla önem kazanmaktadır. Dolayısıyla iş gören-örgüt ilişkisi sadakat ve güven unsurlarını mutlaka taşımalıdır. Bu unsurlar, devamında kaçınılmaz olan bağlılık kavramını gündeme getirir (Kurtbaş, 2011). Örgüt, çalışanlarını nitelikli birer girdi haline dönüştürürse, örgütün işleyişine önemli katkılar sağlamış olur (Can, 2005). Çalışan, örgütünden memnuniyet duyarsa, örgütte bulunan diğer çalışanlarla da sağlıklı ilişkiler kurar (Kaya, 2007).

Örgüte ilişkin pek çok değişkenin örgütsel bağlılık ile ilişkili olduğu ortaya çıkmıştır. Örneğin, iç tanıtım politikaları ve iş güvenliği, örgütsel destek algılarını teşvik edebilir; performansa dayalı ödül politikaları ve çalışan katılımı örgütsel adalet algılarına katkıda bulunabilir; iş mücadelesi ve özerklik, kişisel yeterlilik algılarını destekleyebilir (Chughtai ve Zafar, 2006). Yapılan çalışmalar, terfi alan iş görenlerin kuruma olan bağlllık düzeyini olumlu yönde geliştirdiğini (Bozkaya, 2013), yaş, örgütsel görev süresi, özerklik düzeyi, çalışma saatleri ve sosyal katılım gibi faktörlerin örgütsel bağlılığı önemli ölçüde etkilediğini göstermektedir (Smeenk, Eisinga, Teelken ve Doorewaard, 2006). Benzer şekilde, Guest (1987) örgütsel bağlılığın, örgütsel değişimi tetiklediğini, bu nedenle örgütsel bağlllık, duygusal zeka ve liderlik arasında pozitif yönlü ilişkiler olduğunu Joiner ve Bakalis, (2006) ise mali işler ve düzenli çalışma disiplini gibi diğer örgütsel değişkenlerle bağlantılı olduğu ifade etmiştir.

Yapılan bazı çalışmalara göre, iş görenlerin örgütsel bağlılık düzeyini etkileyen en önemli unsurlardan birisi de yönetici davranışlarıdır (Kılıç, 2008). Yöneticiler, örgütsel bağlılık düzeyini arttırarak çalışanların maddi ve manevi gelişimlerine katkı sağlamakta, çevresel faktörlerle birlikte çalışanların performanslarını arttırmaktadır (Rego \& Cunha, 2008). Bu bağlamda yöneticilerin gösterdikleri liderlik davranışlarının kurumsal bağlılığı etkilediği, otoriter ve baskıcı yöneticilerin çalışanları sınırlandıracağ 1 ve verimsiz hale getireceği söylenebilir (Gündoğan, 2009). Bu nedenle işletmeler, çalışanları yeteneklerine göre yönlendirerek onlardan en yüksek düzeyde faydalanmayı (Gürkan, 2006) örgütsel bağlllı̆̆ mesleki bağllığa dönüştürerek bireyin işini daha etkili bir şekilde sahiplenmesini amaçlamakta (Gündoğan, 2009), çalışanlar ise kendi değerleri ile 
örgütün değerlerinin bir noktada buluşmasını ve kendilerini örgütün bir parçası olarak görmeyi arzulamaktadır (Bülbül, 2007).

İş görenlerin örgüte bağlllık düzeyleri değiştikçe, buna bağlı olarak örgüte yönelik davranışları da değişir. İş görenin örgüte karşı göstermiş olduğu bağlılık düzeyleri örgüte farklı şekilde yansıyarak olumlu veya olumsuz şekilde ortaya çıkmasına neden olabilmektedir (Kılıç, 2008). Çalışanlar örgütlerine bağlılık göstermiyor ve yaptıkları işten memnun değillerse, örgütten duygusal veya zihinsel olarak uzaklaşırlar ve istifa etmek için fırsat ararlar. Bu nedenle örgütsel bağlllık, çalışanların işten ayrılma niyetinin ve çalışanın organizasyona genel katkısının değerlendirilmesinde önemli bir faktördür (Naser, 2007). Örgütsel bağlllı̆̆1 olmayan çalışanlar maddi kazanç sağlayamıyorlarsa örgütleri için daha fazla çalışmaya gönüllü olmamaktadırlar. Ancak çalışan, örgütün kendisinden fedakarlık yapmasını istediğinde gerekli fedakarlığ 1 karşılık beklemeksizin yapıyorsa bu durumda çalışanın örgütsel bağlılığı söz konusu olur (Somuncu, 2008).

Düşük örgütsel bağlllıkta olan bir birey için bireyin yaratıcıllğı ve gelişmeye açıklığının ortaya çıkması olumlu sonuç olarak değerlendirilebilir (Gözen, 2007). Örgüt açısından ise bu düzeyde bulunan çalışanın istek ve şikâyetleri değerlendirilebilirse zamanında gelişim ve değişim olumlu olarak değerlendirilebilir. Olumlu bağlılık çalışanlara hem ücret hem de yetki olarak geri döner (Bozkaya, 2013). Bağlılık düzeyinin yükselmesi ile bireylerin kuruma olan bağlılığı artar. Bu bireyler kendi yetersizliklerini kapatmak için grup içinde daha etkin olmaya çalışırlar (Gözen, 2007). Araştırmalar örgütlerin, çalışanlarda örgütsel bağlılığı arttırmaya yönelik çalışmalar yaptığını ve bu sayede çalışanın verimliliğini arttırmaya çalıştığını göstermektedir (Kök, 2006).

Örgütsel bağlılığın sınıflandırılması ile ilgili en önemli çalışmalardan birisi Allen ve Meyer'in örgütsel bağlılık sınıflandırmasıdır (Mammadova, 2013). Allen ve Meyer örgütsel bağlılığın çeşitli tanımlarında bağlllığ1; çalışanın örgütü ile ilişkisini karakterize eden ve örgüt üyeliğini devam ettirme kararını içeren, bir psikolojik durum olarak ifade etmişlerdir (Yalçın, 2013). Allen ve Meyer, bağlllığın bu üç unsurunu göz önünde tutarak örgütsel bağllıkla ilgili 1984 yılında duygusal bağlılık ve devam bağlılığını içeren bir model geliştirmişler, daha sonra (1990 yılında) ise söz konusu örgütsel bağlllık modellerine, Weiner ve Vardi'nin 
1980 yılındaki çalışmalarını esas alan normatif bağlılık isimli üçüncü bir unsuru eklemişlerdir (Doğrul, 2013).

Devam bağlılığı bir zorunluluğa dayanmaktadır. Çalışan örgütten ayrıldığında, örgütte çalıştığı süre içinde sahip olduğu maddi ve manevi unsurları kaybedeceğini düşünüyor ve bunu göze alamıyorsa çalışan için devam bağlılığı ortaya çıkmış demektir (Sabuncuoğlu, 2007). Kuralc1 (normatif) bağlılıkta çalışanlar, örgüt içerisinde yaşadıkları deneyimlere bağlı olarak örgütün bir parçası olarak kalma noktasında isteklidirler (Arslantürk ve Şahan, 2012). Bu yükümlülük, bireyden sadece örgütün beklentisi sonucunda ortaya çımaz aynı zamanda bireyin ailesi ve ait olduğu toplumun, sadakatin bir erdem olduğu vurgusundan kaynaklanan bir zorunluluktur (Çöl ve Gül, 2005).

İlgili literatürde en çok ele alınan öğe, duygusal bağlllıktır. Duygusal bağll1ık, kişinin örgütle kendini bir kabul etmesi ve kendini örgütün bir unsuru gibi görmesidir (Uslu, 2012). Duygusal bağl1lıkta çalışanlar yaptıkları işe karşı bağlılık oluşturur. Bireyin davranışının ön planda olduğu bu yaklaşıma göre çalışanlar belli bir takım davranışlara bağlanarak hareket etmektedirler (Uslu, 2012). Çalışanların bağlılıkları, özellikle duygusal bağlılık, bağlllık ve sadakatin önemli bir belirleyicisi olarak kabul edilmiştir. Duygusal olarak örgüte kendini adamış çalışanlar, örgütte kalma isteklerini artıran bir aidiyet ve kimlik duygusuna sahip olarak görülmektedir (Rhoades ve Eisenberger, 2001).

Örgütsel bağlılık kavramı işletme tipi örgütlerde ortaya çıkmasına rağmen hızla diğer örgütlere yayılmış, eğitim örgütlerinde de bu kavrama ilişkin çok sayıda araştırma yapılmıştır. Araştırmalar daha çok öğretmen ve okul yöneticileri üzerine yoğunlaşmış, örgütsel bağlılık kavramı çoğunlukla diğer kavramlarla birlikte çalışmalara konu edilmiştir (Coladarc1, 1992; Somers, 1995; Bogler ve Somech, 2004; Feather ve Rauter, 2004; Avolıo, Zhu, Koh ve Bhatıa, 2004; Karaköse ve Bozgeyikli, 2012; Nguni, Sleegers ve Denessen, 2006; Ross ve Gray, 2006; Polat ve uğurlu, 2008; Buluç, 2009; Yılmaz, 2009; Erdem, 2010; Korkmaz, 2011;Uğurlu, Sincar ve Çınarlı 2013;Selvitopu ve Şahin, 2013; Ayık, Savaş ve Yücel, 2015; Okçu, Şahin ve Şahin, 2015). Öğretmen ve okul yöneticileri üzerine yapılan çalışmalar kadar yoğun olmasa da örgütsel bağlılığa ilişkin eğitim alanında yapılan çalışmalar üniversitelerde görev yapan akademik personel bağlamında da araştırmalara dönüşerek literatüre 
önemli katkılar sağlanmıştır (Özmen, Özer ve Saatçioglu, 2005; Güneş, Bayraktaroğlu ve Kutanis, 2009; Maree, Boyle ve Fulop, 2010; Yew, 2011; Aydemir ve Erşan, 2011; Nordin, 2011; Özgan, Külekçi ve Özkan, 2012; Bozkurt ve Yurt, 2013; Güzelbayram, 2013; Tolentino, 2013; Yiğitel, 2014; Wainaina, Iravo ve Waititu, 2014). Akademisyen boyutunda yapılan çalışmalar incelendiğinde bu çalışmaların nicel olarak yürütüldüğü görülmüş, Fisher, Boyle ve Fulop (2010) dişında nitel bir çalışmaya rastlanmamıştır. Bu çalışmada ise öğretim elemanlarının kurumlarına ilişkin örgütsel bağlllık düzeyleri nitel bir çalışma ile betimlenmiştir. Bu bağlamda çalışma, diğer çalışmalardan farklılaşmakta ve literatüre katkı sağlamaktadır. Araştırmanın amacı, öğretim elemanlarının kurumlarına ilişkin örgütsel bağlılık düzeyini öğretim elemanlarının görüşlerine göre değerlendirmektir.

\section{Yöntem}

Bu bölümde araştırmanın deseni, çalışma evreni, örneklemi, veri toplama araçları, veri toplama araçlarının dağıtılması, toplanması ve verilerin nasıl analiz edildiğine ilişkin bilgiler verilmiştir.

\section{Araştırma Modeli}

Araştırma nitel durum çalışması desenine göre yapılandırılmıştır. Durum çalışmalarında, belirlenen konuya ilişkin derinlemesine bilgi edinilmesi amaçlanır. Bir ya da birkaç durum, bağlantılı olduğu değişkenlere göre incelenir, bu değişkenleri nasıl etkilediği ya da bu değişkenlerden nasıl etkilendiği betimlenir (Yıldırm ve Şimşek, 2011). Bu kapsamda öğretim elemanlarının örgütsel bağlılı̆̆ irdelenmesi gereken bir durum olarak ele alınmıştır. Çalışmada örgütsel bağlılık kavramının kendi dinamikleri içerisinde derinlemesine incelenebilmesi için durum çalışması tercih edilmiştir. Yine örgütsel bağlılık konusunda öğretim elemanlarının görüşleri doğrultusunda ortaya çıabilecek değişkenlerin belirlenmesinde, analiz edilmesinde ve sunulmasında durum çalışmasının verimli olacağı düşünülmektedir. 


\section{Çalışma Grubu}

Çalışma grubunun belirlenmesinde amaçlı örnekleme yöntemlerinden maksimum çeşitlilik örnekleme yöntemi kullanılmıştır. Maksimum çeşitlilik örneklemesi ile çeşitlilik gösteren durumların ortak paydalarının bulunması, örneklemi farklı özellikleri ile geniş bir çerçevede yapılandırılması amaçlanmaktadır (Yıldırım ve Şimşek, 2011). Maksimum çeşitlilik örnekleme yöntemi ile cinsiyet, medeni durum, yaş, çalışma süresi ve eğitim durumu değişkenleri ölçüt olarak kabul edilmiş ve bu değişkenlere uygun bir dağılım elde edilmesi amaçlanmıştır. Bu bağlamda Giresun Üniversitesi bünyesinde yer alan 11 meslek yüksekokulun her birinden 2 öğretim elemanı çalışma grubunda yer almıştır. Katılımcılar belirlenirken görüşme yapmayı kabul etme ve katılmaya istekli olma durumu göz önünde bulundurulmuştur. Çalışma grubunu oluşturan öğretim elemanlarına ait bilgiler Tablo 1'de sunulmuştur.

Tablo 1. Öğretim elemanlarına ilişkin bilgiler

\begin{tabular}{lll}
\hline \multicolumn{1}{c}{ Kişisel Bilgiler } & & f \\
\hline \multirow{2}{*}{ Cinsiyet } & Kadın & 9 \\
& Erkek & 13 \\
\hline \multirow{2}{*}{ Medeni Durum } & Evli & 14 \\
& Bekâr & 8 \\
\hline \multirow{2}{*}{ Yaş } & $20-32$ & 11 \\
& $33-45$ & 11 \\
\hline \multirow{2}{*}{ Çalışma Süresi } & 45 ve üzeri & - \\
\hline \multirow{2}{*}{ Eğitim Durumu } & $1-10$ yll & 16 \\
& $11-21$ yıl & 6 \\
& 22 yıl ve üzeri & - \\
\hline
\end{tabular}

Tablo 1'de araştırmanın açık uçlu sorulara yanıt veren öğretim elemanlarının kişisel bilgilerine ilişkin frekans dağılımları yer almaktadır. Buna göre sorulara yanıt veren öğretim elemanlarının, 9'unu kadınlar oluştururken, 13'ünü erkekler oluşturmaktadırlar. Sorulara cevap veren öğretim elemanlarının; 14'ü evli iken 8'i bekâr ; 11'i 20-32, 11'i 33-45 yaş 
grubunda yer almaktadırlar. Öğretim elemanlarının 16'sının 1-10, 6'sının 11-21 yıl çalışma süresi bulunmaktadır. Araştırmaya katılanların 8'ini lisans mezunları, 14'üni yüksek lisans mezunları oluşturmaktadır.

\section{Veri Toplama Arac1}

Araştırma verileri yarı yapılandırılmış görüşme tekniği ile elde edilmiştir. Araştırma soruları hazırlanırken Meyer ve Allen (1997) tarafından geliştirmiş olan 18 maddelik "Üç Boyutlu Görsel Bağlılık Ölçeği" nin Karakuş (2005) tarafından Türk kültürüne "Örgütsel Bağlllık Ölçeği" adıyla 21 madde olarak uyarladığı ölçeğin alt boyutları olan duygusal bağlılık, devam bağlılı̆̆1 ve normatif bağlılık boyutları dikkate alınmıştır. $\mathrm{Bu}$ bağlamda veri toplama aracı araştırmacı ve uzman öğretim üyeleri tarafından geliştirilen ve 6 açık uçlu soruyu kapsayan bir yarı yapılandırılmış görüşme formundan oluşmuştur. Veri toplama aracının geliştirilme sürecinde hazırlanan sorular alanında uzman iki öğretim üyesine ve iki Türkçe öğretmenine incelemeleri için verilmiş, inceleme sonucunda soruların açık ve anlaşılır olduğu saptanmıştır. Ayrıca sorular örneklemde bulunmayan iki öğretim üyesinin cevaplaması sağlanmış, Geri dönütlere dayanılarak soruların son şekli verilmiştir.

Araştırmada katılımcılara yöneltilen sorular şunlardır: 1.Uzun vadeli olarak bu kurumda çalışmayı düşünür müsünüz? Bu bağlamda; Sonda 1.Bu kuruma sizi bağlayan etkenler nelerdir? Sonda 2. Bu kurumdan sizi uzaklaştıran etkenler nelerdir? 2.Kurumda uzun süreli çalışıyor olmanın avantajlarını ve dezavantajlarını Sonda 1.kurum açısından Sonda 2. çalışan açısından nasıl değerlendirirsiniz? 3.Kurumda çalışmaya devam etme isteğiniz ile kuruma bağlılık duymanız arasında bir ilişki var mıdır? 4.Bu kurumdan şu an ayrılmanızı ahlaki sorumluluk açısından nasıl değerlendirirsiniz? 5.Bu kurum sizin bağlılığınızı hak ediyor mu? 6.Kurumunuza karşı bir sorumluluk hissediyor musunuz? Araştırma kapsamında elde edilen sorular 22 katılımcıya yöneltilmiştir.

Elde edilen veri toplama aracı ile Giresun Üniversitesi bünyesinde yer alan 11 meslek yüksekokulun her birinden 2 öğretim elemanıla görüşmeler yapılmıştır. Katılımcılar belirlenirken görüşme yapmayı kabul etme ve katılmaya istekli olma durumu göz önünde bulundu- 
rulmuştur. Görüşmeler Nisan 2014 ayı içerisinde gerçekleştirilmiştir. Gerçekleştirilen görüşmelerde öğretim elemanlarıyla sıcak ve rahat ortam kurulmasına özen gösterilmiştir. Öğretim elemanlarıyla görüşülmeden önce üniversite rektörlügü ile görüşülmüş izin alınmış ve rektörlüğün bilgisi dâhilinde görüşmeler gerçekleştirilmiştir. Böylece öğretim elemanlarının kendilerini daha rahat hissetmeleri sağlanmıştır. Görüşmeler ses kayıt cihazı ile kayıt altına alınmış ve $524 \mathrm{dk}$. ses kaydı elde edilmiştir. Ayrıca görüşme sırasında yazılı notlarda alınmıştır.

\section{Verilerin Analizi}

Görüşme verilerinin yorumlanması sürecinde içerik analizi tekniği kullanılmıştır. İçerik analizi, benzerlik gösteren verileri bir araya getirmek, bu verileri belirli isimler altında toplayarak okuyucuya anlaşılır şekilde sunmaktır. Toplanan veriler için örüntüleri belirleme, kodlama ve akademisyenlerin ortak görüşleri sayısal olarak değerlendirildikten sonra kategorilere ayırma işlemlerini kapsayan içerik analizi tekniği ile analiz edilmiştir (Yıldırım ve Şimşek, 2011). Bu doğrultuda veriler dört aşamada analiz edilmiştir: (1) verilerin kodlanması, (2) temaların bulunması, (3) kodların ve temaların düzenlenmesi, (4) bulguların tanımlanması ve yorumlanması (Yıldırım ve Şimşek, 2011). Bu süreç iki araştırmacı tarafından ayrı ayrı takip edilmiş ve bulgular görüş birliği doğrultusunda kodlara ve temalara ayrılmıştır (K1, K2, K3.......K22) şeklinde rumuzlar verilmiştir. Ayrıca araştırma içinde doğrudan alıntılara yer verilmiştir.

\section{Nitel Araștırmada Geçerlik ve Güvenirlik}

Mills'e (2003) göre, geçerlik ve güvenirlik daha çok nicel araştırmalarda kullanılmakta olup nitel yaklaşımı açıklamakta yetersiz kalmaktadır. Bu yüzden araştırmada geçerlik ve güvenirlik kavramları yerine inandırıc1lık, aktarılabilirlik, tutarlılık ve teyit edilebilirlik kavramları tercih edilmiştir. Bu bağlamda araştırmada Doğan, Uğurlu ve Karakaş'ın (2014) çalışmalarında takip ettiklere sürece benzer olarak:

Araştırmada inandırıcılığı sağlamak için öncelikle araştırmanın uygulama sürecinde tüm görüşmeler ses kayıt cihazıyla ve not alınarak kayıt 
altına alınmıştır. Sonraki aşamada ise veriler word programına aktarılmıştır. Araştırmac1, araştırmanın tüm aşamalarında mümkün olduğunca objektif olmaya dikkat etmiştir. Aktarılabilirlik konusunda araştırmacıların okuyuculara, uygulama ve içerikteki benzerliklere karar vermesi için yeterli detayları vermesi gerekmektedir. Bu nedenle çalışmanın yöntem bölümünde; araştırmanın yapıldığı yer, zaman ve içerik ile ilgili açıklayıcı bir şekilde bilgi verilmiştir. Araştırmanın tutarlılığını artırmak için çalışmada elde edilen bulguların tamamı yorum ve genelleme yapılmadan doğrudan okuyucuya sunulmuştur. Ayrıca araştırma sürecinde elde edilen tüm veriler, araştırmacının kendisi dışında, başka bir araştırmacı tarafından değerlendirip, ayrı ayrı kodlanmış ve tüm kodlamalar arasında genel anlamda görüş birliği sağlanmıştır. İki araştırmacının birbirinden bağımsız olarak kullandıkları kodların tutarlığı "Görüş Birliği” ya da "Görüş Ayrılığı" şeklinde işaretlemeler yapılarak belirlenmiştir. Buna göre nitel verileri inceleyen iki uzman arasında \%82 oranında görüş birliği sağlanmıştır. Araştırmanın teyit edilebilirliğini sağlamak için, verilerin elde edilme süreci detayları ile birlikte sunulmuştur.

\section{Bulgular}

Bu bölümde öğretim elemanlarının görüşme formunda yer alan sorulara verdikleri yanıtlar araştırma amacı doğrultusunda sunulmuştur.

Kuruma Bağlayan ve Kurumdan Uzaklaştıran Etkenlere İlişkin Bulgular ve Yorumlar

Tablo 2. Kuruma bağlayan etkenlerin açıklanmasına yönelik görüşler

\begin{tabular}{llc}
\hline & Katılımcılar & $\mathbf{f}$ \\
\hline İletişim; mutluluk & $K 2, K 5, K 9, K 13, K 22$ & 5 \\
\hline Çalışma ortamı; esneklik & $K 5, K 8, K 9, K 14, K 21$ & 5 \\
\hline Akademik gelişim imkânı; mesleki doyum & $K 5, K 7, K 9, K 17, K 19$ & 5 \\
\hline Ekonomik kazanç; iş garantisi & $K 3, K 17, K 21, K 22$ & 4 \\
\hline Ö̆̆grenci faktörü & $K 9, K 14, K 21$, & 3 \\
\hline Memleket olması & $K 15, K 16, K 19$ & 3 \\
\hline Özerk bir yapıda olması & $K 16$ & 1 \\
\hline Kurumda mesleğe başlama & $K 7$ & 1 \\
\hline Toplam & & $\mathbf{2 7}$ \\
\hline
\end{tabular}


Kuruma bağlayan etkenlerin açıklanmasına yönelik olarak katılımclardan elde edilen görüşler doğrultusunda 8 kategori elde edilmiştir. Ortaya çıkan kategoriler ve kategoriler üzerinde yapılan frekans analizi Tablo 2'de verilmiştir.

Katılımcılar kuruma bağlayan olumlu etkenleri açıklarken, iletişimmutluluk, ekonomik kazanç-iş garantisi, öğrenci faktörü, çalışma ortamıesneklik, memleket olması, akademik gelişim imkânı-mesleki doyum, özerk bir yapıda olması, kurumda mesleğe başlama yargılarına yer verdikleri görülmüştür. Bu bağlamda Katılımcılardan (K2, K5, K9, K13, K22) kurumlarının akademik bağlamda yükselmeye olanak sağlamasının mutluluk verdiğini ve kurum içi insani ilişkilerin çalışma ortamını besleyen bir unsur olduğunu ifade etmişlerdir. Katılımcıların, kuruma bağlayan etkenlerin açıklanmasına yönelik görüşlerinden bazıları aşağıda verilmiştir:

K9 rumuzlu katılımcı kurumdaki iletişimin dostane ilişkiler çerçevesinde gerçekleşmesi beni mutlu ederken kuruma bağlanmamda önemli bir etkendir, K5 rumuzlu katılımcı diğer kamu kuruluşlarının aksine çalışma ortamının esnekliği biz akademisyenlere güvenildiğini gösteriyor ve bu esneklikte bizi bağlllık adına besleyen bir unsur, K5 rumuzlu katılımcı bir çok üniversitede yüksek lisans, doktora eğitimini yapmak isteyenlere zaman açısından izin verilmediği halde ben doktora çalışmamı kurumumda rahatlıkla yapabiliyorum, K17 rumuzlu katılımc kariyer gelişiminin desteklenmesi bizim için bir doyum ve akabinde bağlllı sebebi, K17 rumuzlu katılımc1 ek derslerle birlikte maaşımın beni tatmin etmesi ve bunun sürekliliğini bilmem gelecek kaygısı açısından beni bu kuruma bağlamaktadır, K14 rumuzlu katılımcı öğrencilerimi sevmem ve bu anlamda idealist olmam etkili bir faktördür, söylemlerinde bulunarak kuruma bağl1lılıklarının nedenlerini belirtmişlerdir.

Kurumdan uzaklaştıran etkenlerin açıklanmasına yönelik olarak katılımcılardan elde edilen görüşler doğrultusunda 8 kategori elde edilmiştir. Ortaya çıkan kategoriler ve kategoriler üzerinde yapılan frekans analizi Tablo 3'de verilmiştir: 
Tablo 3. Kurumdan uzaklaştıran etkenlerin açıklanmasına yönelik görüşler

\begin{tabular}{|c|c|c|}
\hline & Katılımcılar & $f$ \\
\hline Kadro yetersizliği & $\begin{array}{l}K 6, K 7, K 9, K 11, K 14 \\
K 19, K 20, K 21, K 17\end{array}$ & 9 \\
\hline Fiziki ve sosyal imkân yetersizliği & $\begin{array}{l}\text { K1, K2, K5, K8, K12, K13, } \\
\text { K15 }\end{array}$ & 7 \\
\hline Ulaşım & $\begin{array}{l}\text { K2, K4, K5, K12, K14, } \\
\text { K19, K21 }\end{array}$ & 7 \\
\hline $\begin{array}{l}\text { Çatışmacı kültür, } \\
\text { gruplaşmalar, insani ilişkiler }\end{array}$ & $\begin{array}{l}\text { K3, K6, K8, K9, K12, K14, } \\
\text { K17 }\end{array}$ & 7 \\
\hline Öğrenci kalitesi & K8, K15, K20, K21, K22 & 5 \\
\hline $\begin{array}{l}\text { Ders ücretlerinin yetersizliği ve zamanında ödeme } \\
\text { olmaması }\end{array}$ & K 9, K16, K18, K19 & 4 \\
\hline Gelişim imkânının olmaması & $K 4, K 8, K 10, K 13$ & 4 \\
\hline $\begin{array}{l}\text { Bıkkınlık, motivasyon } \\
\text { eksikliği, aidiyet eksikliği }\end{array}$ & K3, K16, K18 & 3 \\
\hline
\end{tabular}

Tablo 3'e gore katılımcılar kurumdan uzaklaştıran nedenlere ilişkin önem sırasına gore, kadro yetersizliği, fiziki ve sosyal imkân yetersizliği, ulaşım, çatışmacı kültür, gruplaşmalar, insane ilişkileri, öğrenci kalitesi, ders ücretlerinin yetersizliği ve zamanında ödeme olmaması, gelişim imkanlarının olmaması, bıkkınlık, motivasyon eksikliği, aidiyet eksikliği üzerinde durmuşlardır.

Katılımcıların, kurumdan uzaklaştıran etkenlerin açıklanmasına yönelik görüşlerinden bazıları aşağıda verilmiştir:

Ayrıca K9 rumuzlu katılımcı kadro yetersizliğinden kaynaklanan ders yükünün fazla olmasının çok yorucu ve monoton bir atmosfer oluşturduğu, K7 rumuzlu katılımc1 yeni yapılanma sonucu deneyimsiz personelin yönetici pozisyonunda olmasının örgütsel bağhliğ̆ zedeleyici bir durum olduğu, K8 rumuzlu katılımcı çalışma yaşantısının dışında çalışanları rahatlatabilecek ortamların olmamasinın olumsuz bir etken olduğu, K12 rumuzlu katılımc1 memleketlere ya da akademik çalısma yapılan şehirlere uzak olmanın ve ulaşımın problemli olmasının kurumdan ayrılmak için bir sebep olduğu, K3 rumuzlu katılımcı ideolojik anlamda ortaya çıkan kutuplaşmaların işe ve öğrencilere yansıdı ̆̆ı, söylemlerinde bulunarak kendilerini kurumdan uzaklaştıran unsurları belirtmişlerdir. 
Kurumda Uzun Süreli Çalışmanın Kurum Açısından Avantaj ve Dezavantajlarına İlişkin Bulgular ve Yorumlar

Kurumda uzun süreli çalışmanın kurum açısından avantajlarına yönelik olarak katılımcılardan elde edilen görüşler doğrultusunda 5 kategori elde edilmiştir. Ortaya çıan kategoriler ve kategoriler üzerinde yapılan frekans analizi Tablo 4'de verilmiştir:

Tablo 4. Kurumda uzun süreli çalışmanın kurum açısından avantajlarına yönelik görüşler

\begin{tabular}{lll}
\hline & Katılımcılar & f \\
\hline $\begin{array}{l}\text { Kuruma, çalışma } \\
\text { ilkelerine hâkimiyetin } \\
\text { getirileri; verimlilik }\end{array}$ & $\begin{array}{l}K 5, K 7, K 8, K 9, K 11, \\
K 14, K 18, K 20, K 22\end{array}$ & 9 \\
\hline Sorun çözümünde deneyim & $\begin{array}{l}K 1, K 3, K 12, K 14, K 15, \\
K 16, K 17, K 19\end{array}$ & 8 \\
\hline İşleyişi kolaylaştırma & $K 3, K 4, K 5, K 6, K 7, K 9, K 10$ & 7 \\
\hline $\begin{array}{l}\text { Uyum sürecinin kolaylı̆̆ı, } \\
\text { iletişimde sorun yaşamama }\end{array}$ & $K 6, K 8, K 10, K 13, K 18$ & 5 \\
\hline Denetim ihtiyacının azlığ & $K 2$ & 1 \\
\hline Toplam & & $\mathbf{3 0}$ \\
\hline
\end{tabular}

Katılımcılara göre kurumda uzun süreli çalışmanın kurum için sağladığı avantaj konusunda verimlilik ve sorunların çözümünde deneyimin sağladığı kolaylık ön plana çıkmaktadır. K22 rumuzlu katılımcı kurumun işleyişine ve düzenine hakim olan akademisyenlerin daha etkili ve aktif olduklarını, K14 rumuzlu katılımcı sorunların doğru teşhisinin isabetli çözüm önerileri getirdiği, K1 rumuzlu katılımc1 önemli olabilecek problemlerin çözümünde tecrübeli kalemlerin etkisinin güçlü olduğunu, K6 rumuzlu katılımcı uzun süreli birliktelik sonucu herkesin birbirini olduğu gibi kabul ettiğini, K2 rumuzlu katılımcı ise uzun süreli çalışmanın uzmanlık oluşturduğu dolayısıyla diş kontrollere çok sık gerek kalmadığı söylemlerinde bulunarak bu durumun kurum için bir avantaj olduğunu belirtmişlerdir.

Kurumda uzun süreli çalışmanın kurum açısından dezavantajlarına yönelik katılımcıların görüşleri doğrultusunda 4 kategori elde edilmiştir. Bu kategorilerin frekans analizi Tablo 5'de verilmiştir: 
Tablo 5. Kurumda uzun süreli çalışmanın kurum açısından dezavantajlarına yönelik görüş̧ler

\begin{tabular}{lll}
\hline & Katılımcılar & f \\
\hline $\begin{array}{l}\text { Psikolojik bağın } \\
\text { kopması, monotonluk }\end{array}$ & $K 3, K 7, K 8, K 10, K 14$ & 5 \\
\hline $\begin{array}{l}\text { Kemikleşme, körelme, } \\
\text { değişime kapalı olma }\end{array}$ & $K 7, K 8, K 9, K 11$ & 4 \\
\hline Verimliliğin düşmesi & $K 13, K 19$ & 2 \\
\hline Çatışma & $K 8, K 14$ & 2 \\
\hline Toplam & & $\mathbf{1 3}$ \\
\hline
\end{tabular}

Katılımciların çoğunluğu (K3, K7, K8, K10, K14) bir kurumda uzun süre çalışmanın sonucunda gerek bireysel gerekse kurumsal açıdan psikolojik bağın koptuğunu ve bir süre sonra buna bağlı olarak monotonluğun hakim olduğunu ifade ederlerken K8 ve K14 rumuzlu katılımcılar ise kurumsal ilişkide çatışmayı vurgulamışlardır.

Katılımcıların, kurumda uzun süreli çalışmanın kurum açısından dezavantajlarının açıklanmasına yönelik görüşlerinden bazıları aşağıda verilmiştir:

K14 rumuzlu katılımc1 uzun süreli birliktelik sonucu bir süre sonra sadece fiziksel olarak varlık gösterildiği ve bu durumun kurum işleyişini etkilediği, K7 rumuzlu katılımcı sürekliliğin ilişkileri yıprattı̆̆ını ve bu durumunda kurumsal ilişkiye yansıdığı, K9 rumuzlu katılımcı sürekliliğin yapılan iş adına yeniliklere kulak kapatılmasına neden olduğu, K13 rumuzlu katılımcı yapılan işe yönelik hevesin kaybolduğu ve verimin düştüğ̈̈, $\mathrm{K} 8$ rumuzlu katılımc1 ise ilişkilerin zedelendiği, gruplaşmaların sonucunda çatışma ortamının kaçınılmaz olduğ $u$ söylemlerinde bulunarak dezavantajları belirtmişlerdir.

\section{Kurumda Uzun Süreli Çalışmanın Çalışan Açısından Avantaj ve Deza- vantajlarına İlişkin Bulgular ve Yorumlar}

Kurumda uzun süreli çalışmanın çalışan açısından avantajlarına yönelik olarak katılımcılardan elde edilen görüşler doğrultusunda 4 kategori elde edilmiştir. Ortaya çlkan kategoriler ve kategoriler üzerinde yapılan frekans analizi Tablo 6'da verilmiştir: 
Tablo 6. Kurumda uzun süreli çalışmanın çalışan açısından avantajlarına yönelik görüşler

\begin{tabular}{lll}
\hline & Katılımc1lar & f \\
\hline $\begin{array}{l}\text { Güven, sahiplenme, benimseme } \\
\text { kurum kültürüne uyum, } \\
\begin{array}{l}\text { evlilik gibi özel yaşama dair } \\
\text { sorumluluklar }\end{array}\end{array}$ & $\begin{array}{l}K 2, K 5, K 8, K 13, K 14, \\
\text { K16, K17, K22 }\end{array}$ & 8 \\
\hline $\begin{array}{l}\text { Iletişimde problem yaşamama, } \\
\text { sosyal çevre oluşturma }\end{array}$ & $K 1, K 2, K 7, K 10, K 14, K 18$, & 6 \\
\hline Tecrübe, başarı duygusu & $K 2, K 5, K 12, K 14, K 20$ & 5 \\
\hline $\begin{array}{l}\text { Prosedüre, yönetmeliğe, } \\
\text { göreve hakim olma }\end{array}$ & $K 6, K 15, K 18, K 19$ & 4 \\
\hline Toplam & & $\mathbf{2 3}$ \\
\hline
\end{tabular}

Katılımcılar kurumda uzun süre çalışmanın çalışan açısından avantajlarını açıklarken, güven-sahiplenme-benimseme-kurum kültürüne uyum, özel yaşama dair sorumluluklar tecrübe-başarı duygusu, prosedüre-yönetmeliğe-göreve hakim olma, iletişimde problem yaşamama-sosyal çevre oluşturma yargılarına yer verdikleri görülmüştür. Katılımcıların büyük bir çoğunluğu (K2, K5, K8, K13, K14, K16, K17, K22) kendini kurumun bir parçası olarak görme ve dolayısıyla kurumu sahiplenmenin sonucu olarak çalışanların kurum değerleriyle özdeşleştiğini, katılımcıların bir kısmı da (K1, K2, K7, K10, K14, K18) uzun süreli çalışma sayesinde formel ilişkilerin informel ilişkilere yansıyarak sosyal çevre oluşumunun çalışanı motive edici bir unsur olduğunu ifade etmişlerdir.

Katılımcıların, kurumda uzun süreli çalışmanın çalışan açısından avantajlarının açılanmasına yönelik görüşlerinden bazıları aşağıda verilmiştir:

K8 rumuzlu katılımc1 uzun süre bir kurumda yer alınca bir süre sonra kurumla benzeşmeye başlandığı, K16 rumuzlu katılımc herşeye aşina olmanın kuruma aidiyat hissi oluşturduğu, K22 rumuzlu katılımc1 eş ve çocuklara olan sorumluluk gereği uzun süre çalışmanın hayata dair maceralardan insanı koruduğu, K2 rumuzlu katılımc1 evli olmanın düzenli bir yaşam gerektirdiği, K7 rumuzlu katılımc yöneticileri tanıma nedeniyle informel iletişim kanalları kurularak taleplere yant bulma, tanınma sonucu tolerans sinırının genişlemesinin çalışan için bir avantaj olduğu, K5 rumuzlu katılımcı uzun yıllar aynı kurumda çalışma sonucu deneyimler sayesinde başarmın nerden geldiğinin 
öğrenildiği, K1 rumuzlu katılımcı ezbere kurum adına herşeye hakim olundu$\breve{g}$ unu ifade etmişlerdir.

Kurumda uzun süreli çalışmanın çalışan açısından dezavantajlarına yönelik olarak katılımcılardan elde edilen görüşler doğrultusunda 4 kategori elde edilmiştir. Ortaya çıkan kategoriler ve kategoriler üzerinde yapılan frekans analizi Tablo 7'de verilmiştir:

Tablo 7. Kurumda uzun süreli çalışmanın çalışan açısından dezavantajlarına yönelik görüşler

\begin{tabular}{lll}
\hline & Katılımcılar & f \\
\hline $\begin{array}{l}\text { Motivasyonda düşme, bıkkınlık, } \\
\text { isteksizlik, gevşeme, monotonluk }\end{array}$ & $\begin{array}{l}\text { K2,K6,K9, K10, K11, } \\
\text { K12, K13, K14, K19 }\end{array}$ & 9 \\
\hline $\begin{array}{l}\text { Kemikleşme, bireysel } \\
\text { güç oluşturma }\end{array}$ & $K 8, K 9, K 11$ & 3 \\
\hline $\begin{array}{l}\text { Çevreye duyarsılık, } \\
\text { psikolojik atalet, yıpranma }\end{array}$ & $K 3, K 7$ & 2 \\
\hline $\begin{array}{l}\text { İletişimde sorun, yeni } \\
\text { personelle uyumda problem }\end{array}$ & $K 9, K 21$ & 2 \\
\hline Toplam & & $\mathbf{1 6}$ \\
\hline
\end{tabular}

Katılımciların büyük bir çoğunluğu (K2, K6, K9, K10, K11, K12, K13, K14, K19) bir kurumda uzun süre çalışmanın sonucunda motivasyonda düşme, beklentilerin azalması, bıkkınlık ve bezme, gevşeme, monotonluk kavramlarına yer verdikleri görülmüştür.

Katılımcıların, kurumda uzun süreli çalışmanın çalışan açısından dezavantajlarının açıklanmasına yönelik görüşlerinden bazıları aşağıda verilmiştir:

K12 rumuzlu katılımcı uzun yıllar çalışma ile oluşan dură̆anlığın bezginlik ve monotonluk yarattığı, K11 rumuzlu katılımc kurum içinde kemikleşmenin çalışanların gelişime ve yeniliğe kapalı olması durumunu ortaya çıkardı$\breve{g} \imath$, K7 rumuzlu katılımcı aynı kurumda aynı çevrede ilişki sürdürmenin psikolojik atalet (çeoreye duyarsızlaşma) oluşturduğu, K21 rumuzlu katılımcı ise kurumda göreve yeni başlayanlarla eski çalışanlar arasında ister istemez negatif bir iletişim ortamının olduğu ve çatışmaların yaşandı̆̆ı söylemlerinde bulunarak düşüncelerini ifade etmişlerdir. 


\section{Kurumda Çalışmaya Devam Etme İsteği ile Bağhllık Arasındaki İlişkiye Yönelik Bulgular ve Yorumlar}

Kurumda çalışmaya devam etme isteği ile bağlılık arasındaki ilişkiye yönelik katılımcılardan elde edilen görüşler doğrultusunda 6 kategori elde edilmiştir. Ortaya çıkan kategoriler ve kategoriler üzerinde yapılan frekans analizi Tablo 8'de verilmiştir:

Tablo 8: Kurumda çalışmaya devam etme isteği ile bağhlık arasındaki ilişkiye yönelik görüusler

\begin{tabular}{|c|c|c|}
\hline & Katılımcılar & $\mathrm{f}$ \\
\hline Bağlllık zorunluluktan & K1, K3, K4, K6, K9, & 9 \\
\hline kaynaklaniyor & K11, K19, K20, K21 & \\
\hline $\begin{array}{l}\text { Rahat, huzur, çalışma süresi } \\
\text { arttıkça bağllıkta artar }\end{array}$ & K2, K5, K8, K17, K22 & 5 \\
\hline $\begin{array}{l}\text { Kuruma borçlu hissetme, } \\
\text { minnettarlık }\end{array}$ & $K 1, K 7$ & 2 \\
\hline $\begin{array}{l}\text { Öğrenciyi ortada bırakma } \\
\text { duygusu ile bağlllık paralel }\end{array}$ & K20 & 1 \\
\hline $\begin{array}{l}\text { Memleketimde olmamla } \\
\text { bağllık duygum paralel }\end{array}$ & K16 & 1 \\
\hline $\begin{array}{l}\text { Kurumun bireyin felsefe } \\
\text { ve vizyonuyla uyumlu } \\
\text { olması bağlılık unsuru }\end{array}$ & K13 & 1 \\
\hline Toplam & & 19 \\
\hline
\end{tabular}

Katılımcılara göre kurumda çalışmaya devam etme durumunun kaynağı bağlılık ise o kurumda olumlu bir kurum kültürü ve pozitif bir iklimin olması, ortamda çatışma ve çekişmelerin olmaması ve dolayısıyla huzurun olması, bireyin kurumu benimsemesi, bağlllık ve sadakat için bireyin işe, olaylara ve hayata bakış açısıyla kurumun paralellik göstermesi ve bu doğrultuda talepleri karşılayabilmesi gerekmektedir. Tablo 22'ye göre en çok vurgulanan kavram "huzur" kavramıdır. Ancak tabloya bakıldığında büyük bir çoğunluğun bağlılık kavramıyla "zorunluluk" kavramın ilişkilendirdiği dikkat çekmektedir.

Katılımcıların, kurumda çalışmaya devam etme isteği ile bağlılık arasındaki ilişkinin açıklanmasına yönelik görüşlerinden bazıları aşağıda verilmiştir: 
K3, K9 ve K11 rumuzlu katılımclar kurumun kendileri için bir basamak olduğunu akademik çalışmalarının tamamlanmasıyla hemen gitmek için alternatiflere yönelecekleri, K1 rumuzlu katılımcı maddi kaygıları nedeniyle bağhllı-

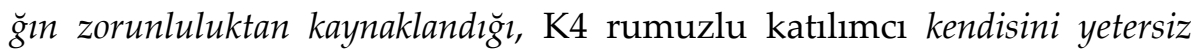
hissettiği, K19 rumuzlu katılımcı şu an yeni bir iş bulmakta zorlanacă̆ı, K8 rumuzlu katılımcı kurum içerisindeki iklimin olumlu olmasının huzur verdiği ve bunun bağlllık yarattığı, K7 rumuzlu katılımcı kendini kuruma borçlu hissettiği ve bu duygunun kendisinde bağhllk nedeni olduğu, K20 rumuzlu katılımcı dönemleri tamamlanmadan öğrencilerini bırakamayacağı için bağlılık duyduğ u, K16 rumuzlu katılımcı görev yaptığ yerin memleketi olması sebebiyle bu kurumda çalışıp ayn kurumdan emekli olmak istediği, K13 rumuzlu katılımc ise kurumunun politik duruşu ve bu doğrultudaki hedefleriyle kendisinin politik duruşunun benzer olması nedeniyle kendini kuruma bağh hissettiğ $i$ söylemlerinde bulunarak düşüncelerini ifade etmişlerdir.

\section{Kurumdan Ayrılmayı Etik ve Etik Dışı Değerlendirmeye İlişkin Bulgular ve Yorumlar}

Kurumdan ayrılmayı etik olarak değerlendiren katılımcılardan elde edilen görüşler doğrultusunda 4 kategori elde edilmiştir. Ortaya çıkan kategoriler ve kategoriler üzerinde yapılan frekans analizi Tablo 9'da verilmiştir:

Tablo 9. Kurumdan ayrılmayı etik olarak değerlendirmeye yönelik görüşler

\begin{tabular}{lll}
\hline $\begin{array}{l}\text { Vicdanım rahat olduğu } \\
\text { için ayrılabilirim }\end{array}$ & Katılımcılar & $\mathbf{f}$ \\
\hline $\begin{array}{l}\text { Şartların gereğini yaparım, } \\
\text { bu durum ahlakla alakalı değil }\end{array}$ & $K 3, K 8, K 13, K 21$ & 4 \\
\hline $\begin{array}{l}\text { Herkes kurum ya da iş } \\
\text { değiştirme hakkına sahiptir }\end{array}$ & $K 1, K 9$ & 3 \\
\hline $\begin{array}{l}\text { Kişilerin kendileri için } \\
\text { çözüm önerileri bulmaları } \\
\text { vefasızlı değildir }\end{array}$ & $K 2$ & 2 \\
\hline Toplam & & 1 \\
\hline
\end{tabular}

Kurumdan ayrılmayı etik olarak değerlendiren katılımcılar, vicdanlarının rahat olduğuna, şartlara bağlı olarak davranmanın gerektiğine, iş 
değiştirme hakkının olduğuna, kişisel çözümlerin kişisel hakkı olduğuna vurgu yapmışlardır. Bu konuda katılımcılara ait bazı görüşler aşağıda verilmiştir:

$\mathrm{K} 3, \mathrm{~K} 8, \mathrm{~K} 13$ ve K21 rumuzlu katılımcllar görevleri gereği yapmaları gereken herşeyi yaptıkların ancak kurumdan ayrılmanın kişisel menfaatlerine yönelik olduğu bir durumda bunun vicdanen bir sıkıntı doğurmayacağını ifade ederken, K10, K16, K20 rumuzlu katılımcılar iş değişikliğinin ahlakla ilişkili bir durum olmadığın yaşamlarına devam edebilmeleri için şartlarla ilişkili olduğunu, K1 rumuzlu katılımc1 emekliliğe kadar insanların aynı kurumda çalışmlarının beklenemeyeceğini ve iş değişikliğinin anayasal bir hak olduğunu, K2 rumuzlu katılımo insanların iş hayatlarındaki şartlarını iyileştirmek istemelerinin vefasızlık olmadığıı ifade etmişlerdir.

Kurumdan ayrılmayı etik dışı olarak değerlendiren katılımcılardan elde edilen görüssler doğrultusunda 2 kategori elde edilmiştir. Ortaya çıkan kategoriler ve kategoriler üzerinde yapılan frekans analizi Tablo 10'da verilmiştir:

Tablo 10. Kurumdan ayrılmayı etik dışı olarak değerlendirmeye yönelik görüşler

\begin{tabular}{lll}
\hline & Katılımcılar & f \\
\hline $\begin{array}{l}\text { Eğitim öğretimi yarıda } \\
\text { bırakmak etik dışıdır }\end{array}$ & $K 4, K 5, K 6, K 14, K 15$, & 8 \\
\hline $\begin{array}{l}\text { Kurumu terk etmek zarar } \\
\text { verici onur kırıııdır }\end{array}$ & $K 5, K 7, K 11, K 13, K 17, K 18$ & 6 \\
\hline Toplam & & $\mathbf{1 4}$ \\
\hline
\end{tabular}

Kurumdan ayrılmayı etik dışı olarak değerlendiren katılımcılar, eğitim öğretim sürecini yarıda bırakmanın etik olmadığına, kurumu bırakmanın ise kuruma zarar vereceğini vurgulamışlardır. Bu konuda katılımcılara ait bazı görüşler aşağıda verilmiştir:

K11 rumuzlu katılımcı kurumdan şu an ayrılmayı doğru bulmadığını çünkü bireylerin çalıştıkları kuruma bir artı kazandırmalarının ahlaki ve vicdani bir durum olduğunu ve sadece kadro akademisyenliğinin doğru olmadığııı ifade ederken K7 rumuzlu katılımcı kurumun, işsizliğin yüksek oranda olduğu bir ülkede genç yaşta bireyleri saygin bir mesleğin üyesi yaptı̆̆ını, gelişim için olanaklar sağladığını ve bu çerçevede akademik unvan elde ettikten sonra ayrılmanın yakışısız olacağını, K5 rumuzlu katılımcı ise öğrencilerini yüzüstü 
bırakma duygusunun kendisini bireysel olarak hırpalayabileceğgini ifade etmişlerdir.

\section{Kurumun Bağlılığı Hakedip Haketmediğine İlişkin Bulgular ve Yorumlar}

Kurumun çalışanın bağlılığını hakettiğine yönelik katılımcılardan elde edilen görüşler doğrultusunda 3 kategori elde edilmiştir. Ortaya çıkan kategoriler ve kategoriler üzerinde yapılan frekans analizi Tablo 11'de verilmiştir:

Tablo 11. Kurumun bă̆lılığı hakettiğine yönelik görüş̧ler

\begin{tabular}{lll}
\hline & Katılımcılar & $\mathbf{f}$ \\
\hline $\begin{array}{l}\text { Sorumluluklarım, öğrencilerim ve } \\
\text { görevim gereği hakediyor }\end{array}$ & $K 1, K 3, K 8, K 13, K 15, K 18, K 20$, & 9 \\
& $K 21, K 22$ & \\
\hline $\begin{array}{l}\text { Değer gördüğüm, } \\
\text { fikirlerim alındığı, } \\
\text { saygı gördüğüm için hakediyor }\end{array}$ & $K 5, K 7$ & 2 \\
\hline $\begin{array}{l}\text { Kurum kendimi gerçekleştirme } \\
\text { imkânın sağladı̆̆ için hakeder }\end{array}$ & $K 14$ & 1 \\
\hline Toplam & & $\mathbf{1 2}$ \\
\hline
\end{tabular}

Kurumun, bağlılığı hakettiğine yönelik görüşler bildiren katılımcılar sorumluluklarına, öğrencilere, kendisine değer verildiğine, kendini gerçekleştirmede fırsatlar sunduğuna vurgu yapmışlardır. Bu konuda katılımcılara ait bazı görüşler aşağıda verilmiştir:

Katılımcıların büyük bir çoğunluğu (K1, K3, K8, K13, K15, K18, K20, K21, K22) kurumun çalışanın bağhllı̆̆ın haketmesinin temel nedenini göreve yönelik yetki ve sorumluluklarının olduğu ve bunun yanı sıra mesleki sevgiden kaynaklanan öğrencilere, ülkeye yönelik sorumlulukları olduğunu ifade etmişlerdir. K13 rumuzlu katılımc1 eğitime gönül vermiş biri olarak ve bu mesleği seçmiş bir gönüllü olarak bağhllğ̆ın mecbur ve vatani bir görev olduğunu düşünüyorum şeklinde ifade ederken, $\mathrm{K} 7$ rumuzlu katılımc1 genç personel istihdam eden, personel haklarına saygll ve aym zamanda diğer üniversitelere göre oldukça ileri durumda olan bir kurumun bağ lılığı hakettiğini ifade etmiştir.

Kurumun, çalışanın bağlılığını haketmediğine yönelik katılımcılardan elde edilen görüşler doğrultusunda 4 kategori elde edilmiştir. Ortaya 
çıkan kategoriler ve kategoriler üzerinde yapılan frekans analizi Tablo 12 'de verilmiştir:

Tablo 12. Kurumun bağhlılı̆̆ı haketmediğine yönelik görüşler

\begin{tabular}{llc}
\hline & Katılımcılar & $\mathbf{f}$ \\
\hline $\begin{array}{l}\text { Ödüllendirme, } \\
\text { değer verme, onure etme ve } \\
\text { adalet olmadığı için hak etmiyor }\end{array}$ & $K 2, K 4, K 6, K 9, K 12, K 17, K 19$ & 7 \\
\hline $\begin{array}{l}\text { Problemlerim karşısında } \\
\text { yanımda değil }\end{array}$ & $K 4, K 10, K 16$ & 3 \\
\hline $\begin{array}{l}\text { Akademik çalışmalar } \\
\text { desteklenmediği için hak etmiyor }\end{array}$ & $K 11$ & 1 \\
\hline $\begin{array}{l}\text { Yeterli ücret almadığım } \\
\text { çin hak etmiyor }\end{array}$ & $K 16$ & 1 \\
\hline Toplam & & $\mathbf{1 2}$ \\
\hline
\end{tabular}

Katılımcılara göre kurum motivasyon açısından ödüllendirme yapmall, bireylere değer vermeli, adil olmalı, tarafsız olmalı, hakkaniyeti gözetmeli, emekleri takdir edip onure etmeli, bilimsel bazda akademik çalışmaları desteklemeli ve bu çerçevede insan yaşam ve onuruna yakışacak şekilde çalışmaları teşvik edecek bir ücret sistemi geliştirmelidir. K17 rumuzlu katılımcı kurum yararına birşeyler yapıldığında dahi bunun ne maddi ne de manevi şekilde onure edilmediğgini, K9 rumuzlu katılımcı çalıştığı kurumda adama göre muamele yapıldığı için sadakati haketmediğini, K4 rumuzlu katılımcı kurumun kesinlikle bağgllığını haketmediğgini çünkü kendini kurumda güvende hissetmediğini ve ufak bir problem durumunda kurumunun kendisinin yanında değil karşısında olduğunu, K11 rumuzlu katılımcı akademik çalışmaların gerek zaman açısından gerekse maddi açıdan desteklenmediğ̊i için sömürüldü̈̆̈̈nü, K16 rumuzlu katılımc1 ise aldı̆̆ı ücretin emeğinin karşıllğg olmadığını ve bu nedenle de kurumun bağhllı̆̆ haketmedi ğini ifade etmişlerdir.

\section{Kuruma Karşı Sorumluluk Hissine İlişkin Bulgular ve Yorumlar}

Kuruma karşı sorumluluk hissinin olduğuna yönelik katılımcılardan elde edilen görüşler doğrultusunda 3 kategori elde edilmiştir. Ortaya çıkan kategoriler ve kategoriler üzerinde yapılan frekans analizi Tablo 13 'de verilmiştir: 
Tablo 13. Kuruma Karşı Sorumluluk Hissinin Olduğuna Yönelik Görüşler

\begin{tabular}{llc}
\hline & Katılımcılar & f \\
\hline $\begin{array}{l}\text { Kuruma, öğrencilere, topluma, } \\
\text { insanlığa karşı sorumluluğum } \\
\text { var }\end{array}$ & \begin{tabular}{l}
$\mathrm{K} 20, \mathrm{~K} 2, \mathrm{~K} 4, \mathrm{~K} 2, \mathrm{~K} 12, \mathrm{~K} 18, \mathrm{~K} 19$, \\
\hline $\begin{array}{l}\text { Görevlerim açısından } \\
\text { sorumluluğum var }\end{array}$
\end{tabular} & $\mathrm{K} 2, \mathrm{~K} 7, \mathrm{~K} 8, \mathrm{~K} 14, \mathrm{~K} 15, \mathrm{~K} 17$ \\
\hline $\begin{array}{l}\text { Kurum beni kabul ettiği için } \\
\text { vicdani sorumluluğum var }\end{array}$ & $\mathrm{K} 5, \mathrm{~K} 10, \mathrm{~K} 11, \mathrm{~K} 16$ & 4 \\
\hline $\begin{array}{l}\text { Maaşımın karşılığını } \\
\text { vermek için } \\
\text { sorumluluklarım var }\end{array}$ & $\mathrm{K} 6, \mathrm{~K} 9$ & 2 \\
\hline $\begin{array}{l}\text { Prensip gereği } \\
\text { sorumluluklarım var }\end{array}$ & $\mathrm{K} 13$ & 1 \\
\hline Toplam & & $\mathbf{2 3}$ \\
\hline
\end{tabular}

Kuruma karşı sorumluluk hissinin değerlendirildiği Tablo 13'de büyük bir çoğunluk (K1, K3, K4, K5, K12, K18, K19, K20, K21, K2) insani sorumluluğu vurgularken bir k1sım katılımclar da (K2, K7, K8, K14, K15, K17) görevsel sorumluluğu vurgulamış, K5, K10, K11, K16 rumuzlu katılımclar vicdani sorumluluk üzerinde dururken diğer katılımcılar (K13, K6, K9) somut ve daha yaşamla özdeşleştirdikleri mali sorumlulukları ifade etmişlerdir. K12 rumuzlu katılımcı hizmet sunduğu topluma, kuruma, paydaşlara hatta insanlı̆̆a karşı bir sorumluluk hissettiğini ifade etmiştir. Kuruma karşı sorumluluk hissinin olmadığına dair olumsuz görüş bildiren öğretim elemanı bulunmamaktadır.

\section{Tartışma}

Araştırma bulgularına göre öğretim elemanlarını kuruma bağlayan etkenlere ilişkin görüşlerinde en çok vurgulanan ifadeler "iletişim, mutluluk", "çalışma ortamı, esneklik" ve "akademik gelişim imkânı, mesleki doyum" olurken, en az vurgulanan iki görüş ise "özerk bir yapıda olmasi" ve "kurumda mesleğe başlama" olmuştur. Kurumdan uzaklaştıran etkenler incelendiğinde, "kadro yetersizliği", "fiziki ve sosyal imkân yetersizliği", "ulaşım" ve " çatışmacı kültürü, gruplaşmalar, insani ilişkiler" görüşleri ön plana çıkmıştır. Katılımcılar kuruma bağlayan etkenlere ilişkin 27 görüş, kurumdan uzaklaştıran etkenlere ilişkin 47 
görüş bildirmiştir. Bu bağlamda katılımcıların kurumlarına ilişkin örgütsel bağlılıklarının yüksek düzeyde olmadığı söylenebilir. Bu araştırma sonucunu destekler nitelikte Smeenk, Eisinga, Teelken ve Doorewaard, (2006) çalışmasında örgütsel bağlılık üzerine yapılan ampirik araştırma sonuçlarının, üniversitelerde ya da farklı akademik kimlikleri olan fakültelerde örgütsel bağlllı̆̆ın etkisinin az olduğunu gösterdiğini ifade etmiştir. Benzer şekilde Özgan, külekçi ve Özkan (2012); Seyal ve Afzaal (2013) Folorunso; Adewale ve Abodunde (2014); Thomas (2008) araştırmalarında akademisyenlerin çalıştıkları üniversiteye bağlılık düzeylerinin orta seviyede olduğu sonucuna ulaşmıştır. Aydemir ve Erşan (2011) çalışmasında öğretim üyelerinin örgütsel bağlılıklarının düşük olmasının nedenlerini öğretim üyelerinin örgütten (üniversiteden) daha çok kariyere bağlı olmalarına, üniversitenin fiziksel ve sosyal olanaklarındaki eksikliklerine, üniversitenin kurumsallaşmasını tamamlayamamış olmasına, artan iş yüküne, kentin öğretim üyelerinin ve ailelerinin beklentilerine uygun şekilde yaşamalarına olanak tanımayacak kadar küçük ve yetersiz olmasına bağlamaktadır. Öğretim üyeleri için ortaya çıkan bu sonuçlar bu araştırma kapsamında çalışma grubunu oluşturan öğretim elemanları içinde benzer bir durum oluşturduğu söylenebilir.

Araştırma bulgularına göre kurumda uzun süre çalışmanın hem kurum hem de çalışan için en çok üzerinde durulan olumlu yönleri, verimlilik, sorunların çözümünde deneyim sonucu sağlanan kolaylık, güven, sahiplenme, benimseme, kurum kültürüne uyum, evlilik gibi özel hayata dair sorumluluklar olurken olumsuz yönleri ise psikolojik bağın kopması, monotonluk ve kemikleşme, körelme, değişime kapalı olma çatışma, motivasyonda düşme, bıkkınlık, isteksizlik, gevşeme, çevreye duyarsızlık, psikolojik atalet, yıpranma şeklinde ortaya çıkmıştır. Kurumda çalışma süresinin uzun olması genellikle çalışanların duygusal bağlılı̆̆ı ile açıklanmaktadır. Bozkurt ve Yurt (2013) çalışmasında, araştırmaya katılan akademik personelin kurumlarına bağlllık sergilediğini ifade ederken bu bağlılığın ise ağırlıklı olarak duygusal yönde olduğunu vurgulamıştır. Arslantürk ve Şahan (2012), Nayir (2013), Yıldız, Akbolat ve Işık (2013) çalışanın kendisini çalıştığı örgüt ile özdeşleştirmesi şeklinde tanımlanan duygusal bağlılık benzer şekilde Joiner ve Bakalis (2006) ve Nordin (2012)'in akademisyenler üzerine 
yaptıkları araştırmalarda da normatif ve devam bağlılığına göre daha fazla yüksek düzeyde çıkmıştır. Tolentino (2015) ise akademisyenlerde duygusal ve normatif bağl1lığın devam bağlllığına göre daha yüksek seviyede olduğu sonucuna varmıştır. Özmen, Özer ve Saatçioğlu, (2005) akademisyenlerin duygusal olarak kurumlarına bağlılık gösterdiklerini ifade ederek bu durumu akademisyenlerin kariyerlerinin geri kalanında da aynı üniversitede kalmak istedikleri, kendilerini çalıştıkları üniversitenin bir parçası olarak algıladıkları şeklinde yorumlamıştır.

Katılımcıların, kurumdan ayrılmayı etik olarak değerlendiren sonuçlara bakıldığında vicdanlarının rahat olması sebebiyle ayrılmayı etik karşılama ve bireylerin kendileri için çözüm önerileri bulmalarının vefasızlık olmadığı görüşleri ön plana çıkmaktadır. Kurumdan ayrılmayı etik dişı olarak değerlendiren sonuçlar incelendiğinde en çok vurgulanan iki görüş eğitim öğretimi yarıda bırakmanın etik dışı olduğu ve kurumu terk etmenin zarar verici onur kırıcı olduğu şeklinde ortaya çıkmıştır. Katılımcıların bu konudaki görüşleri normatif bağlılık kapsamında değerlendirilebilir. Arslantürk ve Şahan (2012)'a göre normatif bağlılığı yüksek olan çalışan, örgütte kalması gerektiğini hissetmektedir. Çöl ve Gül, (2005)'e göre ise bu yükümlülük, bireyden sadece örgütün beklentisi sonucunda ortaya çıkmaz aynı zamanda bireyin ailesi ve ait olduğu toplumun, sadakatin bir erdem olduğu vurgusundan kaynaklanan bir zorunluluktur. Özgan, külekçi ve Özkan (2012)'ın araştırmasına göre öğretim elemanlarının normatif bağlılığ düzeydedir. Özmen, Özer ve Saatçioğlu, (2005) çalışmasında akademisyenlerin örgütlerine özellikle duygusal ve normatif anlamda bağlllık hissetmekte olduklarını ifade etmiştir. Bu durum normatif boyut açısından yorumlandığında ise akademisyenlerin örgütten ayrılmayı doğru bulmadıkları, bu tür bir eylemde bulunursa suçluluk yasayacakları ve üniversitelerine karsı sorumluluk hissettikleri şeklinde bulgularını betimlemiştir.

Kurumda çalışmaya devam etme isteği ile bağllılık arasındaki ilişkiye yönelik sonuçlar incelendiğinde; katılımcılar daha çok rahat, huzur, çalışma süresi arttıkça bağlılığın artması, öğrenciyi ortada bırakma duygusu ile bağlılığın paralel olması, memleketimde olmakla bağlılığın paralel olması ve kuruma borçlu hissetme, minnettarlık görüşleri üzerinde durmuşlardır. Kurumda çalışmaya devam etme isteği ile bağlılık arasın- 
daki ilişkiye yönelik büyük bir çoğunluğun yanıtladığı tek bir olumsuz görüş ise bağlılığın zorunluluktan kaynaklanması olduğu ortaya çıkmıştır. Katılımcıların kurumda çalışmaya devam etme konusunda daha çok neden ortaya koymuş olmaları, devam bağlılıklarının düşük düzeyde olduğu şeklinde yorumlanabilir. Sabuncuoğlu (2007) devam bağlılığını, çalışanların, örgütten ayrılmaları durumunda sahip olduklarını kaybetme korkusu olarak tanımlamaktadır. Bozkurt ve Yurt (2013) araştırmasında akademik personelin baplılık konusunda en düşük eğiliminin maliyet odaklı bağl1lığı içeren devam bağlılığı boyutunda olduğu sonucuna ulaşmıştır. Özgan, külekçi ve Özkan, ( 2012) araştırmasında öğretim elemanlarının devam bağlılığının diğer bağlılık türlerine göre daha düşük düzeyde olduğu sonucuna ulaşmıştır. Güzelbayram, (2013) araştırmasında, okutmanların okulda bulunmaktan hoşnut oldukları ve okulun koyduğu kurallara gerekli olduklarına inandıkları için uyduklarını, benzer şekilde, okul yöneticilerinin okutmanların bağlılıklarını arttırmak için yaptıkları çeşitli uygulama ve çabalardan memnun kaldıklarını ifade etmektedir. Ancak aynı araştırmada okutmanların başka bir yerde çalışma olanağı buldukları takdirde birikimlerini dikkate almaksızın bu olanağı değerlendirebileceklerine yönelik ortaya çıkan ifadeler, okutmanların devam bağlllığının düşük olduğunu göstermektedir. Özmen, Özer ve Saatçioğlu (2005) araştırmasında akademisyenlerin devam bağlılığını düşük olduğunu ifade etmiştir. Yazarlara göre devamlılık boyutuna ait zayıflığın gerekçesi de yine mesleğin kendi doğası ve bilgi isçilerinin özellikleri ile açıklanabilir. Akademisyenler yaptıkları işi bir yasam biçimi olarak benimsemektedirler, dolayısıyla çoğunlukla bu isi maddi kaygılarla sürdürmezler. Ayrıca bilgi isçisi olmaları nedeniyle, akademisyenlikten vazgeçmeleri durumunda örgüt dişına çıtıklarında da pek çok alternatif bulabilecek bir grubun üyesidirler.

Kurumun, çalışanın bağlılığını hakettiğine yönelik sonuçlar incelendiğinde, katılımcıların görüşlerinde en çok ön plana çıkan görüşler kurumun bireyin sorumlulukları, öğrencileri ve görevi gereği bağlılığı hak ettiği, kurumun bireyin kendini gerçekleştirmesine olanak sağladığ için bağlılığı hak ettiği ortaya çıkmıştır. Kurumun çalışanın bağlılığını haketmediğine yönelik sonuçlarda ise katılımcılar, kurumda ödüllendirme, değer verme, onure etme ve adalet olmadığı için kurumun bağlılığı hak etmediği, akademik çalışmaların desteklenmemesi ve yeterli ücretin 
alınmaması üzerine kurumun bağllığı hak etmediği şeklinde ifadeler kullanmışlarıdır. Kuruma karşı sorumluluk hissinin olduğuna yönelik bulgularda ise kuruma, öğrencilere, topluma ve insanlığa sorumluluğun olduğu ve prensipler gereği sorumlulukların olması gerektiği vurgulanmıştır. Katılımcılara göre kurumun bağlılık konusunda güçlü ve zayıf yönleri vardır. Bu bağlamda kurumda güçlü bağlılık özelliklerini arttırıcı önlemler alınması gerektiği söylenebilir. Akademisyenlerin örgütsel bağlılığının sağlanması konusunda Lew (2009) üniversiteler, eğitim ve maddi izinleri konusundaki yatırımlarının tanıtımlarını yaparak, mali destek programlarını geliştirip daha iyi idari kararlar alarak, Seyal ve Afzaal (2013) yüksek öğretim kurumlarının örgütsel bağlllık düzeyini arttırmaya yönelik politikalar üreterek hem ellerindeki akademisyenleri fakültede tutabileceklerini hem de iyi akademisyenler kuruma kazandırabileceklerini ifade etmiştir.

Örgütlerin başarılarındaki en önemli faktörlerden birisi, sahip oldukları insan kaynaklarıdır. Nitelikli, kendini örgütsel amaçları gerçekleştirmeye adamış ve sadık insan kaynakları, kurumlar için sürdürülebilir tek rekabet üstünlügüdür (Aydemir ve Erşan, 2011). Bu ifadeyi doğrular nitelikte Kipkebut (2010) akademisyenler üzerine yaptığı araştırmasında insan kaynakları yönetiminin örgütsel bağlılıktan pozitif yönde etkilendiğini ifade etmiştir. Araştırma bulgularına dayanılarak aşağıdaki öneriler sunulmuştur:

Örgütün çalışanlarına kişisel gelişim imkânı sağlaması çalışanların kariyer hedeflerini desteklemektedir. Bu doğrultuda kurumlar, çalışanlar için kendilerini geliştirme ve yükselme imkânları sağlamalıdır.

Araştırmada öğretim elemanlarında örgütsel bağlılı̆̆ın oluşturulması ve devamı konusunda çalışanlarla birlikte üst yönetiminde sorumluluğunun çok önemli olduğunu vurgulamaktadırlar. Bu doğrultuda yönetim politikalarında çalışanları ödüllendirme, onore etme, takdir etme, çalışanlara değer verme, çalışanların isteklerini göz ardı etmeme gibi motive edici unsurlara daha fazla yer verilmesi önerilebilir.

Araştırma da katılımcılar, örgütsel bağlılığı yüksek olan öğretim elemanlarının, görevlerini yerine getirirken örgütün sorunlarının çözümünde gönüllü olarak yer aldıkları ve örgütlerinde uzun süre çalışmaktan zevk alacaklarını dile getirmektedirler. Bu bağlamda sorunların çö- 
zümünde ve kararların alınmasında çalışanların görüşlerinin alınmasının akademik kültürün bir parçası haline getirilmesi önerilebilir.

Katılımcıların görüşlerine göre kurumların bağlılık oluşturmada kullandıkları maddi tatmin ediciler tek başlarına yetersizdir. Bu doğrultuda kurumların bağlılık oluşturma ve bu bağl1lığı devam ettirmede çalışanların fiziki ve sosyal imkânlarının arttırılması önerilebilir.

Katılımcların görüşlerine göre çalışanların uzun süreli olarak kurumda kalmalarının sonucu monotonluk, motivasyonda düşme, bıkkınlık sonuçlarının ortaya çıtığı tespit edilmiştir. Verimi düşürebilecek bu sonuçların ortadan kaldırılması için örgütlerin yeniliklerin öncüsü ve takipçisi olması gerekmektedir.

Örgüte olan bağlılığın zorunluluktan kaynaklanması gibi olumsuz durumların örgüt içi huzur, pozitif iletişim, çalışma esnekliği ve bu kapsamda özetle olumlu bir iklim ve kültür ile ortadan kaldırılması önerilebilir.

Örgütsel bağl1lığın örgütlerin gelişiminde olan değeri bilinmelidir. Özellikle toplumların gelişiminde büyük rol oynayan eğitim ve bilim örgütleri olan üniversitelerin insanlığa ve topluma katkısı düşünülerek bu bağlamda üniversitelerin kurumlarında yer alan çalışanların istek ve beklentilerini dikkate alarak bağlılık düzeylerini artırmaları gerekmektedir. Bu doğrultuda çeşitli zamanlarda örgütsel bağlllıkla ilgili mevcut durum analizleri yapılmalıdır. 


\title{
EXTENDED ABSTRACT
}

\section{Opinions of Instructors On Organizational Commitment: A Case Study}

\author{
* \\ Soner Doğan - Ayşad Gonca Güner \\ Cumhuriyet University, Giresun University
}

Individuals work in line with job descriptions given to them in organizations as employees. While organizations expect employees to act in line with job descriptions, they also want them to make sacrifices for the organization within the context of informal relations. In this context, in terms of the development and continuity of the organization, employees' perspectives on organization and behaviors of adopting the organization gain importance. Every organization expects to be accepted by its employees and expects them to perform their services in the best possible way. In meeting these expectations, employees' trust, faith, love and commitment, as a product of all of these, come to the fore in today's management approach. Cooper-Hakim and Viswesvaran (2005) have conducted an impressive amount of research over the past thirty years to understand the nature, premises and results of organizational commitment. According to these studies, high-level employee commitment makes significant contributions to organization's development.

Allen and Meyer's organizational commitment classification is one of the most important studies related to the classification of organizational commitment (Mammadova, 2013). In their various definitions of organizational commitment, Allen and Meyer defined commitment as a psychological state that characterizes the employee's relationship with his/her organization and involves the decision to maintain his/her membership in organization (Yalçın, 2013). In 1984, Allen and Meyer developed a model including emotional commitment and continuance commitment in relation to organizational commitment considering these three elements of commitment and added a third element later, called 
normative commitment, to these organizational commitment models based on Weiner and Vardi's study in 1980 (Doğrul, 2013).

Although organizational commitment concept emerged in business organizations it has spread rapidly to other organizations, and a large number of studies have been conducted in educational organizations regarding this concept. Studies focused primarily on teachers and school administrators, and concept of organizational commitment became the subject of studies mostly with other concepts. In this qualitative research, faculty members' organizational commitment levels towards their institutions were described. In this context, the study differs from other studies and contributes to literature. The aim of the study is to evaluate faculty members' levels of organizational commitment to their institutions according to their views.

The study was structured according to the qualitative case study pattern and the data were collected using a semi-structured interview form developed by the researchers. The study group included 22 instructors who worked in 11 vocational schools in Giresun University. Categories and themes were obtained analyzing the data received as a result of the face-to-face interviews with the participants using content and descriptive analysis methods. According to the findings of the study, the factors that enable instructors to provide commitment to their institutions were as follows: healthy communication in the institution, flexibility of the working environment, trust toward the institution and adaptation to the corporate culture. Lack of staff, inadequacy of physical and social facilities, difficulties in transportation, conflicts and grouping were the factors that prevented instructors to provide commitment to their institutions. instructors' level of commitment to their institutions could be listed as emotional, normative and continuity commitment when evaluated the results. According to the findings of the research, suggestions for strengthening the organizational commitment in the institution have been developed.

Based on the research findings, the following recommendations are presented:

The organization's providing personal development to its employees supports their career goals. In this respect, institutions should provide self-development and promotion opportunities for employees. 
In the research, it is emphasized that, besides employees, senior management also has a significant responsibility for the formation and continuation of organizational commitment in faculty members. In this respect, it may be advisable to include more motivating elements such as rewarding, honoring and appreciating employees, valuing them and not ignoring their wishes in management policies.

In the research, participants expressed that the instructors with high organizational commitment would voluntarily participate in the solution of organization's problems while fulfilling their duties and they would enjoy working in their organizations for a long time. In this context, it is advisable that taking employees' opinions in solving problems and making decisions is worked up into a part of the academic culture.

According to participants' views, material rewards alone used by institutions to create commitment are inadequate. In this respect, it may be suggested that institutions should increase employees' physical and social means to create and maintain commitment.

According to participants' opinions, it was determined that monotony, decreased motivation and boredom occur as a result of employees' working in an organization for a long time. Organizations should be pioneers and followers of innovation to eliminate these consequences that can reduce productivity.

\section{Kaynakça / References}

Adekola, B. (2012). The impact of organizational commitment on job satisfaction: A study of employees at Nigerian Universities. International Journal of Human Resource Studies, 2(2), 1-17.

Arslantürk, G. ve Şahan S. (2012). Örgütsel adalet ve örgütsel bağlılık arasındaki ilişkinin Manisa il emniyet müdürlüğü örnekleminde incelenmesi. Polis Bilimleri Dergisi 14(1), 135-159.

Ayık, A., Savaş, M. ve Yücel, E. (2015). İlkokullarda görev yapan okul müdürlerinin genel öz yeterlik ile örgütsel bağl1lık algıları arasındaki ilişkinin incelenmesi. Uşak Üniversitesi Sosyal Bilimler Dergisi, (22), 193-218.

Aydemir, M. ve Erşan, C. (2011). Yeni kurulan üniversitelerde örgütsel bağlllık sorunu. Afyon Kocatepe Üniversitesi İktisadi ve İdari Bilimler Fakültesi Dergisi, 13(1), 55-72. 
Avolio, B. J., Zhu, W., Koh, W., ve Bhatia, P. (2004). Transformational leadership and organizational commitment: Mediating role of psychological empowerment and moderating role of structural distance. Journal of Organizational Behavior: The International Journal of Industrial, Occupational and Organizational Psychology and Behavior, 25(8), 951-968.

Bogler, R., ve Somech, A. (2004). Influence of teacher empowerment on teachers' organizational commitment, professional commitment and organizational citizenship behavior in schools. Teaching and teacher education, 20(3), 277-289.

Bozkaya, E. (2013). Örgüt çalışanlarının kişilik özellikleri ile örgütsel bağlllıkları arasındaki ilişkinin incelenmesi: hiyerarşik yapısı yüksek bir kurumda uygulama. Yayınlanmamış yüksek lisans tezi. Balıkesir Üniversitesi, Sosyal Bilimler Enstitüsü, Balıkesir.

Bozkurt, Ö. ve Yurt, İ. (2013). Akademisyenlerin örgütsel bağlllık düzeylerini belirlemeye yönelik bir araştırma. Yönetim Bilimleri Dergisi, 11(22), 121-139.

Buluç, B. (2009). Sınıf öğretmenlerinin algılarına göre okul müdürlerinin liderlik stilleri ile örgütsel bağl1lık arasındaki ilişki. Kuram ve Uygulamada Egitim Yönetimi Dergisi, 15(1), 5-34.

Bülbül, M. (2007). Örgütsel bağlllık ve kamu kuruluşlarına yönelik bir araştırma. Yayınlanmamış yüksek lisans tezi, Kahramanmaraş Sütçü İmam Üniversitesi, Sosyal Bilimler Enstitüsü, Kahramanmaraş.

Can, H. (2005). Organizasyon ve yönetim. Ankara: Siyasal.

Chughtai, A. A. ve Zafar, S. (2006). Antecedents and consequences of organizational commitment among Pakistani university teachers. Applied H.R.M. Research, 11(1), 39-64.

Coladarci, T. (1992). Teachers' sense of efficacy and commitment to teaching. The Journal of experimental education, 60(4), 323-337.

Cooper-Hakim, A. ve Viswesvaran, C. (2005). The construct of work commitment: Testing an integrative framework. Psychological Bulletin, 131(2), 241-259.

Çöl, G. ve Gül, H. (2005). Kişisel özelliklerin örgütsel bağlllık üzerine etkileri ve kamu üniversitelerinde bir uygulama. İktisadi ve İdari Bilimler Dergisi, 19(1), 291-306. 
Doğan, S., Uğurlu, C. T. ve Karakaş, H. (2014) Etkili sınıf yönetimi uygulamalarına ilişkin öğretmen görüşlerinin değerlendirilmesi. Gaziantep University Journal of Social Sciences, 13(4), 1097-1119.

Doğrul, M. A. (2013). Örgütsel bağlllık ve örgütsel vatandaşlık davranışı arasındaki ilişki: Afyon meslek yüksekokulunda çalışanlar üzerinde bir araştırma. Yayınlanmamış yüksek lisans tezi, Afyon Kocatepe Üniversitesi, Sosyal Bilimler Enstitüsü, Afyonkarahisar.

Erdem, M. (2010). Öğretmen algılarına göre liselerde iş yaşamı kalitesi ve örgütsel bağlllıkla ilişkisi. Kuram ve Uygulamada Egitim Yönetimi Dergisi, 16(4), 511-537.

Feather, N. T. ve Rauter, K. A. (2004). Organizational citizenship behaviours in relation to job status, job insecurity, organizational commitment and identification, job satisfaction and work values. Journal of occupational and organizational psychology, 77(1), 8194.

Fisher, R., Boyle, M. V. ve Fulop, L. (2010). How gendered is organizational commitment? The case of academic faculty. International Journal of Organizational Analysis, 18(3), 280-294.

Folorunso, O. O., Adewale, A. J. ve Abodunde, S. M. (2014). Exploring the effect of organizational commitment dimensions on employees performance: An empirical evidence from Academic Staff of Oyo State Owned Tertiary Institutions, Nigeria. International Journal of Academic Research in Business and Social Sciences, 4(8), 275-286

Gözen, D. E. (2007). İş tatmini ve örgütsel bağhllık sigorta şirketleri üzerine bir uygulama. Yayınlanmamış yüksek lisans tezi, Atılım Üniversitesi Sosyal Bilimler Enstitüsü, Ankara.

Guest, D. (1987). Human resource management and industrial relations. Journal of Management Studies, 24, 503-521.

Gündoğan, T. (2009). Örgütsel bă̆gllık: Türkiye Cumhuriyet Merkez Bankası uygulaması. Uzmanlı yeterlilik tezi, Türkiye Cumhuriyet Merkez Bankası İnsan Kaynakları Genel Müdürlüğü, Ankara.

Güneş, İ., Bayraktaroğlu, S. ve Kutanis, R. Ö. (2009). Çalışanların örgütsel bağlılık ve tükenmişlik düzeyleri arasındaki ilişki: Bir devlet üniversitesi örneği. Süleyman Demirel Üniversitesi İktisadi ve İdari Bilimler Fakültesi Dergisi, 14(3), 481-497. 
Gürkan, Ç. G. (2006). Örgütsel bağlllık: örgütsel iklimin örgütsel bağlllık üzerindeki etkisi ve trakya üniversitesinde örgüt iklimi ile örgütsel bağlılık arasındaki ilişkinin araştırılması. Yayınlanmamış yüksek lisans tezi, Trakya Üniversitesi, Sosyal Bilimler Enstitüsü, Edirne.

Karakuş, M. (2005). Ortaöğretim kurumlarında görev yapan öğretmenlerin

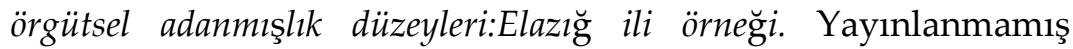
yüksek lisans tezi, İnönü Üniversitesi, Sosyal Bilimler Enstitüsü, Malatya.

Güzelbayram, Ş. (2013). Vakıf üniversitelerinde çalışan okutmanların örgütsel bağlllık düzeylerinin belirlenmesi. Journal of Higher Education \& Science/Yüksekögretim ve Bilim Dergisi, 3(1), 57-64.

Joiner, T. A. ve Bakalis, S. (2006). The antecedents of organizational commitment: the case of Australian casual academics. International journal of educational management, 20(6), 439-452.

Karaköse, B., Bozgeyikli, H. (2012) Örgütsel bağlılık ve çalışma yaşamı kalitesi arasındaki ilişki: Rehberlik araştırma merkezlerinde çalışan personel üzerine bir çalışma. HAK-İŞ Uluslararası Emek ve Toplum Dergisi, 1(2), 185-202

Kaya, O. (2007). Örgütsel bağhllık: emniyet genel müdürlüğ̈̈ merkez biriminde bir uygulama. Yayınlanmamış yüksek lisans tezi, Gazi Üniversitesi, Eğitim Bilimleri Enstitüsü, Ankara.

Kılıç, G. (2008). Kariyer yönetimi ve örgütsel bağlllık arasındaki ilişki: Beş yıldızlı otel işletmelerinde bir araştırma. Yayınlanmamış doktora tezi, Gazi Üniversitesi, Eğitim Bilimleri Enstitüsü, Ankara.

Kipkebut, D. J. (2010). Human resource management practices and organizational commitment in higher educational institutions: A Kenyan case. IUP Journal of Organizational Behavior, 9, 44-70.

Kök, B. S. (2006). İş tatmini ve örgütsel bağlllı̆̆ın incelenmesine yönelik bir araştırma. İktisadi ve İdari Bilimler Dergisi, 20(1), 291-317.

Kurtbaş, D. (2011). Akademisyenlerin maruz kaldıkları psikolojik şiddet ile örgütsel bağlllık arasındaki ilişki kamu ve vakıf üniversitelerinde bir araştırma. Yayınlanmamış yüksek lisans tezi, Gazi Üniversitesi, Eğitim Bilimleri Enstitüsü, Ankara.

Korkmaz, M. (2011). İlköğretim okullarında örgütsel iklim ve örgüt sağlığının örgütsel bağlılık üzerindeki etkisi. Kuram ve Uygulamada Egitim Yönetimi Dergisi, 17(1), 117-139. 
Lew, T. (2009). The relationships between perceived organizational support, felt obligation, affective organizational commitment and turnover intention of academics working with private higher educational institutions in Malaysia. European Journal of Social Sciences, 9(1), 72-87.

Mammadova, İ. (2013). İs tatmini ile örgütsel bağlllık arasındaki ilişki ve bir uygulama. Yayınlanmamış yüksek lisans tezi, İstanbul Aydın Üniversitesi, Sosyal Bilimler Enstitüsü, İstanbul.

Mills, G. E. (2003). Action research a guide for the teacher researcher (2 nd. edition). Boston:Pearson Education.

Naser. S (2007). Exploring Organizational Commitment and Leadership Frames within Indian and Iranian Higher Education Institutions. Bulletin of Education and Research. 29(1), 17 - 32.

Nayir, F. (2013). İlköğretim okulu yöneticilerinin örgütsel bağlllık düzeyi, İlköğretim Online, 12(1), 179-189.

Nguni, S., Sleegers, P. ve Denessen, E. (2006). Transformational and transactional leadership effects on teachers' job satisfaction, organizational commitment, and organizational citizenship behavior in primary schools: The Tanzanian case. School effectiveness and school improvement, 17(2), 145-177.

Nordin, N. (2011). The influence of emotional intelligence, leadership behaviour and organizational commitment on organizational readiness for change in higher learning institution. Procedia-Social and Behavioral Sciences, 29, 129-138.

Nordin, N. (2012). The influence of leadership behavior and organizational commitment on organizational readiness for change in a higher learning institution. Asia Pacific Education Review, 13(2), 239-249.

Okçu, V., Şahin, H. M. ve Şahin, E. (2015). Beden eğitimi ve spor öğretmenlerinin örgütsel sinizme ilişkin algılarının örgütsel bağlılıkları üzerindeki etkisi. International Journal of Science Culture and Sport, 3(Special Issue 4), 298-313.

Özmen, Ö. T., Özer, P. S. ve Saatçioğlu, Ö. Y. (2005). Akademisyenlerde örgütsel ve mesleki bağlılığın incelenmesine ilişkin bir örnek araştırma. İşletme Fakültesi Dergisi, 6(2), 1-14. 
Özgan, H., Külekçi, E. ve Özkan, M. (2012). Analyzing of the relationships between organizational cynicism and organizational commitment of teaching staff. International Online Journal of Educational Sciences, 4(1), 196-205.

Polat, S. ve Uğurlu, C.T. (2009). İlköğretim müfettişlerinin örgütsel bağlılık, mesleki tükenmişlik ve işten ayrılma niyetleri arasındaki ilişki. Education Sciences, 4(3), 1150-1159.

Rego, A. ve Cunha, M.P.E. (2008). Workplace spirituality and organizational commitment: An empirical study. Journal of Organizational Change Management, 21, 53-75.

Rhoades, L., Eisenberger, R., ve Armeli, S. (2001). Affective commitment to the organization: The contribution of perceived organizational support. Journal of applied psychology, 86(5), 825-836.

Sabuncuoğlu, E.T. (2007). Eğitim, örgütsel bağlllık ve işten ayrılma niyeti arasındaki ilişkilerin incelenmesi. Ege Akademik Bakış, 7(2), 621-636.

Selvitopu, A. ve Şahin, H. (2013). Ortaöğretim öğretmenlerinin örgütsel adalet algıları ile örgütsel bağlılıkları arasındaki ilişki. Ahi Evran Üniversitesi Kırşehir Eğitim Fakültesi Dergisi, 14(2), 171-189.

Seyal, A. H. ve Afzaal, T. (2013). An investigation of relationship among emotional intelligence, organizational commitment and job satisfaction: evidence from academics in Brunei Darussalam. International Business Research, 6(3), 217-228.

Simon, H. (1991). Organizations and markets. Journal of Economic Perspectives, 5(2), 25-44.

Smeenk, S. G., Eisinga, R. N., Teelken, J. C. ve Doorewaard, J. A. C. M. (2006). The effects of HRM practices and antecedents on organizational commitment among university employees. The International Journal of Human Resource Management, 17(12), 2035-2054.

Somoncu, F. (2008). Örgütsel bağhllık ve örgütsel bağlllığı geliştirme araçları: özel bir hizmet işletmesinde araştırma. Yayınlanmamış yüksek lisans tezi, Anadolu Üniversitesi, Sosyal Bilimler Enstitüsü, Eskişehir.

Somers, M. J. (1995). Organizational commitment, turnover and absenteeism: An examination of direct and interaction effects. Journal of organizational Behavior, 16(1), 49-58. 
Sökmen, A. (2000). Ankara'daki beş yıldızl konaklama işletmelerinde örgütsel bağlllık ile iş gören performansı arasındaki ilişkinin belirlenmesine yönelik ampirik bir araştırma. Yayınlanmamış yüksek lisans tezi, Gazi Üniversitesi, Sosyal Bilimler Enstitüsü, Ankara.

Tolentino, R. C. (2013). Organizational commitment and job performance of the academic and administrative personnel. International journal of Information technology and Business Management, 15(1), 51-59.

Thomas, J. C. (2008). Administrative, faculty, and staff perceptions of organizational climate and commitment in Christian higher education. Christian Higher Education, 7(3), 226-252.

Uğurlu, C. T., Sincar, M. ve Çınar, K. (2013). Effect of ethical leadership behaviours on the teachers' ethical commitment level in secondary schools. Journal of Education Faculty, 15(1), 266-281.

Uslu, A. (2012). Örgütsel bağgllık, daimi ve geçici işçilerin örgütsel bağhllık algiları üzerinde bir araştırma ve Muş şeker fabrikasinda bir alan çalışması. Yayınlanmamış yüksek lisans tezi, Kahramanmaraş Sütçü İmam Üniversitesi, Sosyal Bilimler Enstitüsü, Kahramanmaraş.

Yalçın, Y. N. (2013). Psikolojik güçlendirme ve örgütsel bağlllık arasındaki ilişki. Yayınlanmamış yüksek lisans tezi, İstanbul Üniversitesi, Sosyal Bilimler Enstitüsü, İstanbul.

Yew, L. T. (2011). Understanding the antecedents of affective organizational commitment and turnover intention of academics in Malaysia: The organizational support theory perspectives. African Journal of Business Management, 5(7), 2551-2562.

Yıldırım A., Şimşek H. (2011). Sosyal bilimlerde nitel araştırma yöntemleri. Ankara: Seçkin.

Yıldız, G., Akbolat M. ve Işık O. (2013). Psikolojik taciz ve örgütsel bağlılık: sağlık çalışanları üzerine bir araştırma. Manas Sosyal Araştırmalar Dergisi, 2(6), 85-117.

Yılmaz, K. (2009). Özel dershane öğretmenlerinin örgütsel güven düzeyleri ile örgütsel vatandaşlık davranışları arasındaki ilişki. Kuram ve Uygulamada Egitim Yönetimi Dergisi, 15(3), 471-490. 
Yiğitel, S. (2014). Öğretmen ve akademisyenlerin algıladıkları liderlik tarzları ile örgütsel bağlllıkları arasındaki ilişki, Yayımlanmamış yüksek lisans tezi, İstanbul Kültür Üniversitesi Sosyal Bilimler Enstitüsü Psikoloji Anabilim Dalı Endüstri ve Örgüt Psikolojisi Bilim Dalı, İstanbul.

Wainaina, L., Iravo, M. ve Waititu, A. (2014). Effect of employee participation in decision making on the organizational commitment amongst academic staff in the private and public universities in Kenya. International Journal of Advanced Research in Management and Social Sciences, 3(12), 131-142.

\section{Kaynakça Bilgisi / Citation Information}

Doğan, S. ve Gonca-Güner, A. (2019). Öğretim elemanlarının örgütsel bağlılığa ilişkin görüşleri: Bir durum çalışması. OPUSUluslararası Toplum Araştırmaları Dergisi, 11(18), 839-876. DOI: 10.26466/opus.543495 